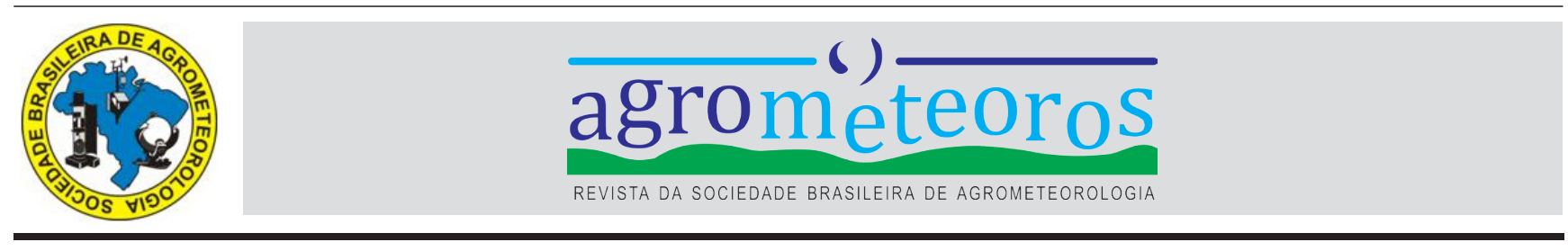

\title{
Mitigating the effects of future climate on maize productivity
}

\author{
Bruna Gomes Magalhães ${ }^{1}$, Camilo de Lelis Teixeira de Andrade ${ }^{2(*)}$, Daniela de Carvalho Lopes ${ }^{3}$, Antonio José Steidle Neto ${ }^{3}$ and \\ Tales Antônio Amaral ${ }^{2}$ \\ ${ }^{1}$ União Pioneira de Integração Social. SEPS Q 712/912 Conj. A, Asa Sul, CEP 70390-125 Brasília, DF, Brazil. E-mail: edu.brunamagalhaes@gmail.com. \\ ${ }^{2}$ Embrapa Maize and Sorghum. Rodovia MG 424, km 45, P.O. Box 285 or 151, CEP 35701-970 Sete Lagoas, MG, Brazil. \\ E-mails: camilo.andrade@embrapa.br and tales_aamaral@yahoo.com.br. \\ ${ }^{3}$ Federal University of São João del Rei. Rodovia MG 424, km 47, CEP 35701-970 Sete Lagoas, MG, Brazil. \\ E-mails: danielalopes@ufsj.edu.br and antonio@ufsj.edu.br. \\ ${ }^{(*)}$ Corresponding author.
}

\section{ARTICLE INFO}

Article history:

Received 23 July 2019

Accepted 11 March 2020

\section{Index terms:}

global warming

mathematical modeling

mitigating strategies

Zea mays L.

\section{ABSTRACT}

Current climate changes affect agricultural production. Crop management strategies can be used to mitigate these effects. This study was carried out to evaluate the use of crop and soil management strategies to mitigate the effects of future climate on maize yield in mesoregions of the state of Minas Gerais, Brazil. The CSM-CERESMaize model was used to simulate the effect of maize root system depth and of the amount of plant residue left on the soil surface by the previous crop in maize yield for different scenarios of change in precipitation and solar radiation. The decrease in rainfall volume reduced the average maize yield in some regions by more than $50 \%$. The increase in solar radiation maize yield rise, while its reduction caused more than $20 \%$ yield drop in most regions. The management strategies evaluated have the potential to mitigate such effects.

\section{Introduction}

Despite the large number of policy actions to minimize the potential negative effects of climate change, the emission of greenhouse gases (GHG), whether or not resulted from anthropogenic actions, has increased in recent years (IPCC, 2014). The raise in the concentration of these gases in the Earth's atmosphere, mainly $\mathrm{CO}_{2}$, intensifies the greenhouse effect, causing changes specially in air temperature (NASA, 2010), rainfall regime and, consequently, in solar radiation. These climatic changes influence the agricultural production IPCC, 2013) since crop yield depends on the interactions of the plants with those meteorological elements.

The change in the rain patterns is a one of the problems arising from climate change (Mulungu \& Ng'ombe, 2019). Rainfed crop systems are totally dependent on meteorological variations and are inevitably influenced by quantity, intensity and distribution of rainfall. Long period of drought causes water stress; the amount of water in the plant tissue reduces, resulting in stomata closure, loss of turgidity of leaves, leading to developmental impairment and ultimately reduction of yield (Bergamaschi \& Matzenauer, 2014). 
Changes in the solar radiation rates also compromise the plant development due to the effect of that meteorological element in the photosynthetic process. The excess of solar radiation causes light stress and also increases the crop evapotranspiration, which under the same rainfall volume and soil-water retention capacity reduces grain yield. On the other hand, there may be a decrease in yield due to the lower incident solar radiation, even when the other climatic elements and the soil moisture are adequate to the crop (Alves et al., 2011). Crop grain yield is related to the amount of photosynthetically active radiation (RFA) that is absorbed by the leaves and also to the efficiency with which these leaves use RFA in the photosynthetic process (Bergamaschi \& Matzenauer, 2014).

The maize (Zea mays L.) is of considerable importance as food and fodder, as well as for Brazil's exports. In the state of Minas Gerais, Brazil, it has been observed an increase in the area of maize grown offseason (IBGE, 2020) which makes the crop even more susceptible to the climate instabilities. Strategies can be taken to cope with the problem, including breeding and soil and crop management practices.

Some crop management practices have the potential to mitigate the effects of global climate change on maize crops among them the no-tillage cropping system stands out. In this system the crop is sown without soil tillage and with the presence of residues from the previous crop. The mulching protects the soil surface, favors water infiltration by changing the porous soil geometry; reduces soil temperature variations due to increased reflection coefficient (albedo) and decreases the evaporation (Moreira et al., 2011).

Other promising mitigating measures are the selection of genotypes with higher root development capacity (Kell, 2011) and the correction of soil profile acidity. The plant search for water and nutrients depends on the root distribution in the soil profile, which, in turn, depends on the soil physical and chemical conditions that, are susceptible to changes function of management. In Brazil, high level of soil compaction the 0.1-0.2 $\mathrm{m}$ layer has been observed under no-till conditions (Franchine et al., 2011), which can limit both root and aboveground crop growth (Bergamin et al., 2010; Labegalini et al.; 2016). Two other factors that also influence the development of the crops rooting system are the presence of toxic aluminum $\left(\mathrm{Al}^{3+}\right)$ and the low $\mathrm{pH}$ of the soil profile. The process used to correct this problem is liming, which raises soil $\mathrm{pH}$, neutralizing the toxic aluminum (Zandoná et al., 2015). Therefore, these two measures have the potential to favor the vertical growth of the plants rooting system and are especially important where the conditions of water supply to the crops are irregular.

Taking into account the interaction between the factors that affect agricultural production and the need to evaluate future scenarios of meteorological variations, modeling appears as an appropriate approach, as it minimizes experimentation costs and optimizes the time of analyze. In this sense the crop growth model DSSAT Decision Support System for Agrotechnology Transfer (Jones et al., 2003; Hoogenboom et al., 2017) stands out, since it allows the evaluation of the dynamics of water and nutrients in the soil and the effects of management strategies on crop yield.

Some studies have been carried out to evaluate the effects of climate change on crops (Moraes et al., 2011; Folberth et al., 2014; Walter et al., 2014; Bragança et al., 2016; Castillo, 2016, Tigchelaara et al., 2018; Geng et al., 2019). However, few studies have evaluated the use of crop management and adaptation strategies (Amadu et al, 2020) to mitigate the effect of such changes in meteorological conditions on crop performance.

Considering the social and economic importance of maize to the state of Minas Gerais, Brazil and the crop's susceptibility to the effects of climate change, this work was developed with the objective of evaluate, crop management strategies with potential to mitigate such effects.

\section{Materials and Methods}

The study encompasses ten meso regions of the state of Minas Gerais, Brazil (Figure 1). The process-based simulation model CSM-CERES-Maize of DSSAT system (Jones et al., 2003) was used to simulate scenarios of different crop management strategies with potential to mitigate possible negative effects of climate changes on maize yield.

Historical series containing 33 years of daily meteorological data from each of the ten regions were obtained from the National Institute of Meteorology (INMET) database. The consistency of the data was evaluated and the failures of up to seven days were filled using the WheatherMan tool (Pickering et al., 1994) of DSSAT. Missing data for periods longer than seven days were filled in with data from nearby meteorological stations with similar elevation. Consistent data were processed in the climate file format and used as input to the DSSAT model.

Samples of the layers $0-0.05 \mathrm{~m}, 0.05-0.20 \mathrm{~m}, 0.20-0.40$ $\mathrm{m}, 0.40-0.70 \mathrm{~m}$ and $0.70-1.00 \mathrm{~m}$ of the soil profile were collect at farms and at experimental stations of Federal Education Institutes, of the same regions, to determine the physical-hydric and chemical attributes of the soil. The analyses consisted on the determination of soil bulk and particle densities, upper and lower limits of available water, saturated soil hydraulic conductivity, fertility and nitrogen. The dataset were processed and also used as 
Figure 1. Geographic location of the study regions, in the state of Minas Gerais, Brazil.

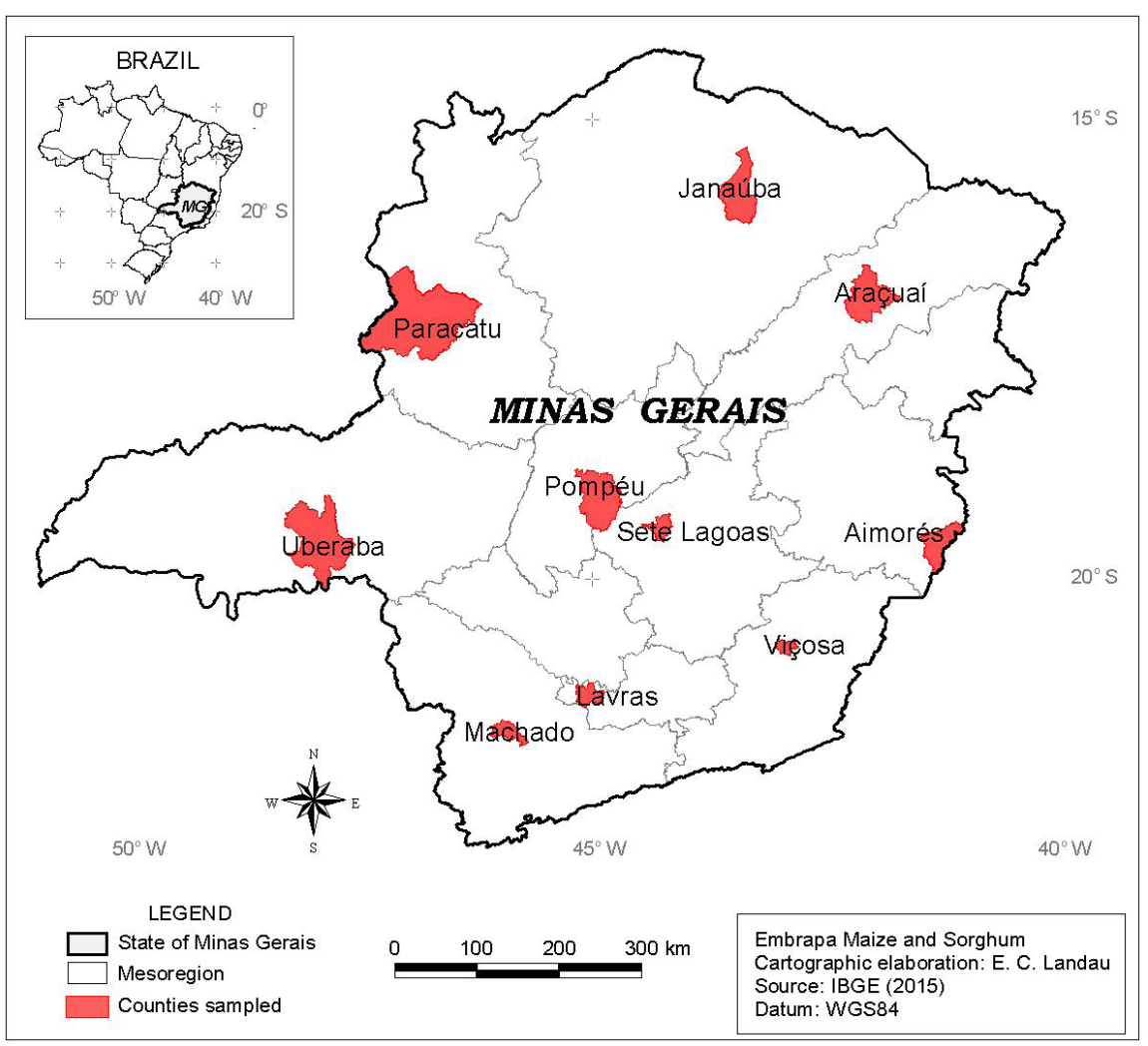

input into the DSSAT model.

The CSM-CERES-Maize model of the DSSAT system, version 4.6.1 (Hoogenboom et al., 2017) was parameterized and evaluated for the single-cross hybrid DKB390PRO using data from 15 experiments carried out in Sete Lagoas, Papagaios, Patos de Minas and Paracatu, in the state of Minas Gerais, in addition to Rio Verde, in the state of Goiás (Andrade et al., 2016). The cultivar DKB390PRO presents an early cycle, a well-developed root system, height of 2.25 to $2.45 \mathrm{~m}$ and high yield potential. The grain is hard with an orange-yellow color (DEKALB, 2019). The thermal sum from emergency to the end of the juvenile stage is 263 degree-days while the rate of grain filling during the linear grain filling stage, under optimum growth conditions, is $4.97 \mathrm{mg} \mathrm{day}^{-1}$ (Table 1).

Data obtained in conditions without biotic and abiotic stresses were used to adjust the coefficients P1, P2, P5, PHINT, G2 and G3, related to the phenology and the crop growth rate, which are specific for each cultivar. Data obtained with some water stress were used to evaluate the predictive capacity of the model. The model was able to accurately simulate the growth and development processes of the maize cultivar, including the length of cycle and grain yield (Andrade et al., 2016).

The seasonal analysis tool of DSSAT was used to perform simulations, which were scheduled to start 30 days before the maize sowing date so that the water and nitrogen balance in the soil approached real field conditions. It was considered a high-yield maize crop sown in a no-tillage system, compatible with the high productive potential of
Table 1. Genetic coefficients for the hybrid DKB390PRO.

\begin{tabular}{|c|c|c|c|}
\hline $\begin{array}{l}\text { Cultivar- } \\
\text { Specific } \\
\text { Coefficien }\end{array}$ & Description & Unit & $\begin{array}{l}\text { Estimated } \\
\text { Value }\end{array}$ \\
\hline P1 & $\begin{array}{l}\text { Thermal sum from } \\
\text { emergency to the end of } \\
\text { the juvenile phase. }\end{array}$ & Degree-Day & 263 \\
\hline P2 & Sensitivity to photoperiod. & Day & 0.5 \\
\hline P5 & $\begin{array}{l}\text { Thermal sum between } \\
\text { flowering and physiological } \\
\text { maturity. }\end{array}$ & Degree-Day & 1087 \\
\hline G2 & $\begin{array}{l}\text { Maximum number of grains } \\
\text { per plant. }\end{array}$ & & 713 \\
\hline G3 & $\begin{array}{l}\text { Rate of grain filling during } \\
\text { the linear grain filling stage, } \\
\text { under optimum conditions. }\end{array}$ & mg day-1 & 4.97 \\
\hline PHINT & $\begin{array}{l}\text { Thermal sum required for } \\
\text { successive appearance of } \\
\text { leaves. }\end{array}$ & Degree-Day & 45.50 \\
\hline
\end{tabular}

the DKB390PRO. The stand was 68,000 plants per hectare with a row spacing of $0.70 \mathrm{~m}$ and planting depth of $0.05 \mathrm{~m}$. Preliminary simulations of weekly sowings were performed using the historical meteorological data set which allowed the identification, for each region, the date that provides the highest simulated average grain yield under rainfed conditions (Table 2).

It was consider in the simulations a nitrogen $(\mathrm{N})$ fertilization of $40 \mathrm{~kg} \mathrm{ha}^{-1}$ of $\mathrm{N}$, as mono-ammoniumphosphate (MAP), applied at sowing; $150 \mathrm{~kg} \mathrm{ha}^{-1}$ of $\mathrm{N}$, as 
Table 2. Regions with their respective sowing dates that provided the highest yield.

\begin{tabular}{|ll}
\hline Mesoregion & Best Sowing Date \\
\hline Aimorés & October 17 \\
\hline Araçuaí & October 17 \\
\hline Janaúba & October 17 \\
\hline Lavras & September 12 \\
\hline Machado & October 31 \\
\hline Paracatu & October 17 \\
\hline Pompéu & October 17 \\
\hline Sete Lagoas & October 10 \\
\hline Uberaba & January 02 \\
\hline Viçosa & October 03 \\
\hline
\end{tabular}

urea, side-dressed at 25 days after sowing (DAS) and $150 \mathrm{~kg}$ ha $^{-1}$ of $\mathrm{N}$, as ammonium sulphate, side-dressed at 40 DAS. The effects of fertilization with phosphorus and potassium was not simulated nor the effect of stresses caused by pests, diseases and weeds. Regardless of the sowing date and region it was considered as initial condition that the soil was at $50 \%$ of its available water capacity. The initial amount of nitrogen available to the plants was estimated from the soil organic carbon content.

The model was set to simulate different scenarios of crop management strategies that have the potential to mitigate the effects of climate change as follow: 1 - (Rz30) - A maize crop with root system depth concentrated on the $0.30 \mathrm{~m}$ top layer; a common problem observed when a cultivar with low tolerance to $\mathrm{Al}^{3+}$ or to low $\mathrm{pH}$ is used, and/or a soil profile with physical impairment or not properly corrected for $\mathrm{Al}^{3+}$ and $\mathrm{pH}$; this is an indirect effect, since the model does not yet simulate the effect of soil acidity on root growth; 2 - (Rz50) - A maize crop with root system depth of $0.50 \mathrm{~m}$; the baseline scenario; a typical maize crop grown in tropical Brazilian soils (Albuquerque, 2010; Rodrigues et al., 2017); 3 - (Rz70) - A maize crop with root system depth of $0.70 \mathrm{~m}$ due to the use of a cultivar bred to deepen the root system or a soil profile very well corrected employing, for instance, gypsum and/ or a subsoiler; 1 - (Cobo) - An inadequate no-till system that does not provide proper crop residue at soil surface; 2 - (Cob2) - A median-managed no-tillage system, which leaves $2 \mathrm{t} \mathrm{ha}^{-1}$ of crop residue on the soil surface (Ceccon, 2007); the baseline scenario; 3 - (Cob4) - A well-managed no-tillage system, which leaves $4 \mathrm{t} \mathrm{ha}^{-1}$ of crop residue on the soil surface. Then, DSSAT was set to run under a combination of decrease and increase of daily rainfall and solar radiation: 1 - (P-50) - 50\% reduction in rainfall; 2 (P-25) - 25\% reduction in rainfall; 3 - (P-0) - No change in rainfall; $4-(\mathrm{P}+25)-25 \%$ increase in rainfall; $5-(\mathrm{P}+50)-$ $50 \%$ increase in rainfall; 1 - (Rad-25) $-25 \%$ reduction in the solar radiation; 2 - (Rad-0) - No change in solar radiation;
$3-(\mathrm{Rad}+25)-25 \%$ increase in solar radiation; $4-(\mathrm{Rad}+50)$ $-50 \%$ increase in solar radiation.

These scenarios follow the protocol provided by the effort to compare and improve crop simulation models AgMIP - The Agricultural Model Intercomparison and Improvement Project (http://www.agmip.org/). It is an international effort that aims to deepen studies related to climate change and to compare crop simulation models. The linear perturbation of the climate data provided by this international effort presents some extreme changes. According to the real climate change trend, one does not expect, for example, such exacerbated increase in daily solar radiation of up to $50 \%$.

Changes in climate elements data, combined with different depths of root system and amounts of crop residue left on the soil surface, generated 90 scenarios. The simulation of those scenarios allowed the evaluation of the effectiveness of crop and soil management strategies as mitigating measures to cope with the climate changes. These changes were considered one at a time by altering the rainfall data and, after, the solar radiation. It was considered in the simulations a concentration of carbon in the air of around 410 ppmv available in version 4.6.1 of the DSSAT model, which was also used in the parameterization process of the cultivar DKB390PRO.

The simulated results were statistically compared to identify what combination of crop management strategies would be the most effective to mitigate the effects of climate changes on maize crop. The yield data for 33 years generated by the model were submitted to analysis of variance in a factorial scheme in a randomized complete block design. Subsequently, the Tukey test was applied at $5 \%$ probability for comparison of means. Each mesoregions of the state of Minas Gerais, Brazil was evaluated individually by comparing its treatments (scenarios). The ANOVA and the means comparisons were executed using the software SISVAR 5.6 (Ferreira, 2011).

\section{Results and Discussion}

As compared to the baseline (scenario without change in rainfall), for all regions, the simulated yield was reduced due to decrease in rainfall (Figure 2). Santos et al. (2011) also reported a reduction in maize yield when evaluating the response of the crop to drought in climate change scenarios in the state of Minas Gerais, Brazil.

The highest drop in yield, for all regions, was simulated for the scenario of a crop with a radicular system $0.3 \mathrm{~m}$ deep and without crop residue in the soil surface (Rz30Cobo). In this scenario, Janaúba presented $59 \%$ reduction in yield due to $50 \%$ drop in rainfall (Figure $2 \mathrm{C}$ ). The regions that presented the highest decrease in yield have in common high temperature and low average annual rainfall, as 
Figure 2. Percentage change in maize crop yield for different scenarios of rainfall change and of soil and crop management mitigation strategies.
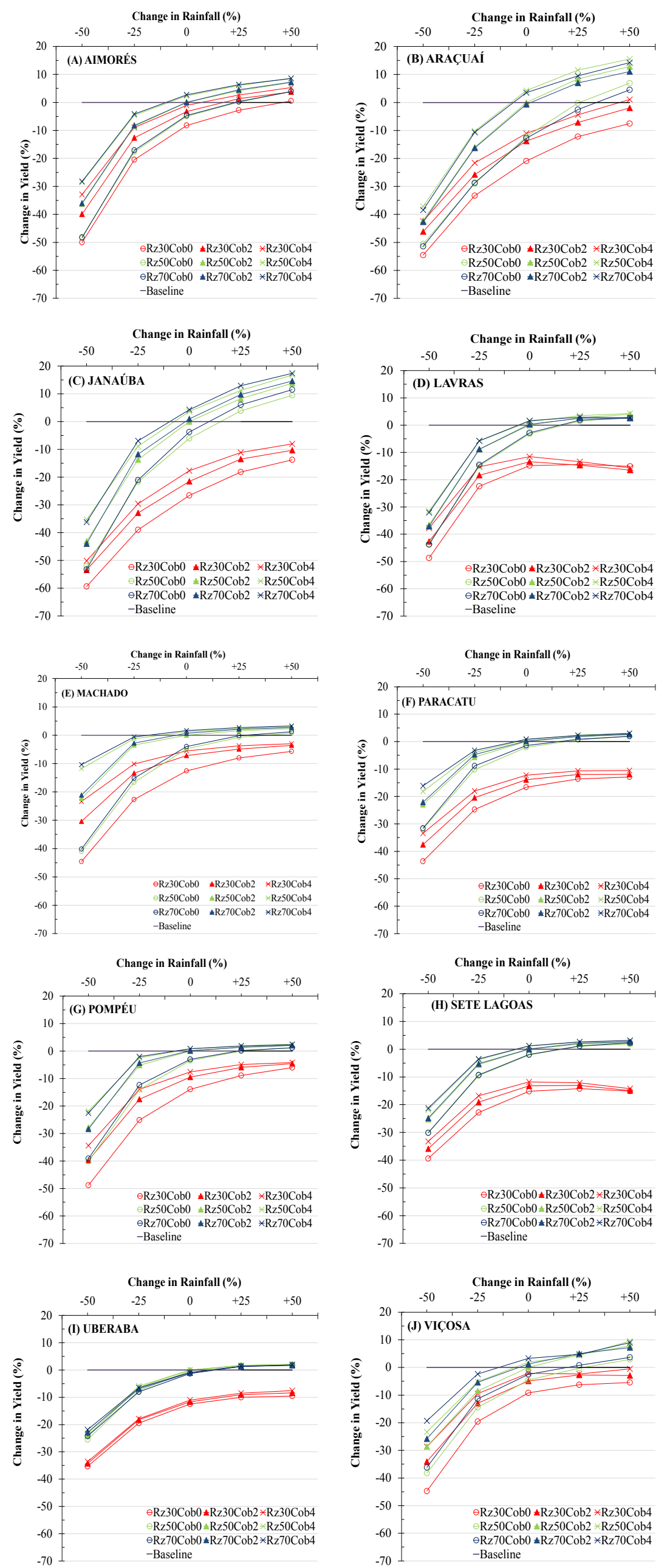
compared to the others. The decrease in grain yield was attenuated for scenarios with deeper root systems and larger amount of crop residue left on the soil surface. In general, the most efficient mitigating scenarios were those that considered $4 \mathrm{t} \mathrm{ha} \mathrm{a}^{-1}$ of crop residue in the soil surface and a crop with a root system 0.5 and $0.7 \mathrm{~m}$ deep.

When evaluating the scenario of rainfall increase, the region of Janaúba presented a yield gain of over 17\% in response to $50 \%$ raise in the rainfall for a cultivar with a root system of $0.7 \mathrm{~m}$ and $4 \mathrm{tha} \mathrm{h}^{-1}$ of crop residue on the soil surface (Figure 2C). In regions with water restrictions for maize crops, such as Janaúba, increased rainfall amounts has a considerable positive effect.

The regions of Lavras and Sete Lagoas (Figures 2D and $2 \mathrm{H}$ ) showed a decrease in yield in response to the increase in rainfall for scenarios of shallow root system (Rz30Cob0, Rz30Cob2 e Rz30Cob4). The lower nitrogen availability in the soil due to nitrate leaching out of that shallow layer caused by increased rainfall volume in these sites, which already have good average annual rainfall, has negative effects on maize crop (Table 3). With the shallow root system, the plant has a lower chance to uptake nitrogen as nitrates become rapidly unavailable in the superficial layers and, therefore, the maize crop presents lower than expected grain yield. It is known that, if there is a restriction to root growth, the plant may have its development compromised (Moraes, 2017). With mitigating strategies involving deeper root systems the crop growth and development restrictions is attenuated.

In order to expresses its productive potential maize requires between 500 and $800 \mathrm{~mm}$ of water during the cycle (FAO, 1991). Therefore, a 50\% reduction in the rainfall amounts in all regions tends to cause yield drops. The simulation results indicated that in Aimorés, Araçuaí and Janaúba the annual rainfall amounts was well below that required by the maize crop which would, therefore, affect its yield. In other regions this would not happen, even with
Table 4. Average annual rainfall of the regions after applying the percentage of changes in the historic values.

\begin{tabular}{lccccc}
\hline & \multicolumn{5}{c}{ Annual average rainfall (mm) } \\
Mescenarios \\
\cline { 2 - 6 } & P-50 & P-25 & P0 & P+25 & P+50 \\
\hline Aimorés & 489 & 733 & 978 & 1222 & 1467 \\
\hline Araçuaí & 379 & 568 & 758 & 947 & 1136 \\
\hline Janaúba & 399 & 598 & 797 & 997 & 1196 \\
\hline Lavras & 749 & 1123 & 1498 & 1872 & 2246 \\
\hline Machado & 764 & 1146 & 1528 & 1910 & 2292 \\
\hline Paracatu & 733 & 1099 & 1466 & 1832 & 2198 \\
\hline Pompéu & 621 & 932 & 1243 & 1553 & 1864 \\
\hline Sete Lagoas & 692 & 1038 & 1384 & 1730 & 2076 \\
\hline Uberaba & 825 & 1238 & 1650 & 2063 & 2475 \\
\hline Viçosa & 663 & 995 & 1327 & 1658 & 1990 \\
\hline
\end{tabular}

a $50 \%$ reduction, since the rainfall volume received by the crop would still meet maize water requirement.

The interactions that were significant in the analysis of variance (root depth $\mathrm{x}$ rainfall and amount of crop residue $\mathrm{x}$ rainfall) were unfolded in order to evaluate the effects of their interactions on yield (Tables 5 e 6). Thus, Tukey's tests, at $5 \%$ probability, were performed for crop residue amount, rainfall and root depth. Lavras and Janaúba presented similar results. Regardless of the change in rainfall $(-50 \%,-25 \%$, no change, $+25 \%$ and $+50 \%)$, considering a cultivar with root system $0.3 \mathrm{~m}$ deep, the average yields were statistically different. On the other hand, no statistical difference was detected for a cultivar with root system of 0.5 and $0.7 \mathrm{~m}$. (Table 5). Thus, in an environment with rainfall depth well above the maize crop requirements the use of cultivar with a root system $0.5 \mathrm{~m}$ deep tends to be sufficient to attenuate the negative effects of some reduction in rainfall volume.

When assessing the interaction between the amount of residue left in the soil by the previous crop and the

Table 3. Average maximum and minimum temperatures, annual rainfall and elevation of the regions.

\begin{tabular}{|lccccc|}
\hline Mesoregion & $\begin{array}{c}\text { Average maximum } \\
\text { temperature in } \mathbf{3 3} \\
\text { years }\left({ }^{\circ} \mathbf{C}\right)\end{array}$ & $\begin{array}{c}\text { Average minimum } \\
\text { temperature in } \mathbf{3 3} \\
\text { years }\left({ }^{\circ} \mathbf{C}\right)\end{array}$ & $\begin{array}{c}\text { Average } \\
\text { temperature in } \mathbf{3 3} \\
\text { years }\left({ }^{\circ} \mathbf{C}\right)\end{array}$ & $\begin{array}{c}\text { Average total } \\
\text { rainfall in 33 years } \\
(\mathbf{m m})\end{array}$ & $\begin{array}{c}\text { Elevation of the } \\
\text { weather station }(\mathbf{m})\end{array}$ \\
\hline Aimorés & 31.8 & 20.3 & 26.0 & 978 & 73 \\
\hline Araçuaí & 31.7 & 19.6 & 25.7 & 797 & 289 \\
\hline Janaúba & 31.4 & 19.0 & 25.2 & 1498 & 516 \\
\hline Lavras & 27.3 & 15.1 & 21.2 & 1528 & 919 \\
\hline Machado & 27.4 & 14.5 & 21.0 & 1466 & 873 \\
\hline Paracatu & 29.9 & 18.2 & 24.1 & 1243 & 712 \\
\hline Pompéu & 29.8 & 16.9 & 23.3 & 1384 & 691 \\
\hline Sete Lagoas & 28.6 & 16.8 & 22.4 & 1650 & 732 \\
\hline Uberaba & 29.4 & 15.8 & 23.1 & 1327 & 737 \\
\hline Viçosa & 26.9 & & 21.4 & 712 \\
\hline
\end{tabular}


Table 5. Unfolding the analysis of variance for the interaction between depth of root system and change in rainfall.

\begin{tabular}{|c|c|c|c|c|}
\hline \multirow{2}{*}{ Mesoregion } & \multirow{2}{*}{$\begin{array}{l}\text { Changes in } \\
\text { Rainfall }\end{array}$} & \multicolumn{3}{|c|}{ Root System Depth (m) } \\
\hline & & 0.3 & 0.5 & 0.7 \\
\hline \multirow[t]{5}{*}{ Araçuaí } & P-50 & $2694 \mathrm{Aa}$ & $2922 \mathrm{Aa}$ & $2877 \mathrm{Aa}$ \\
\hline & P-25 & $3769 A b$ & $4205 \mathrm{Bb}$ & 4197Bb \\
\hline & P0 & $4366 \mathrm{Ac}$ & $5017 \mathrm{BC}$ & 4983BC \\
\hline & $\mathrm{P}+25$ & $4746 \mathrm{Ad}$ & 5494Bd & 5393Bd \\
\hline & $P+50$ & 5009Ad & $5759 B d$ & $5664 B d$ \\
\hline \multirow[t]{5}{*}{ Janaúba } & P-50 & $2462 A a$ & 3045Ba & 2992Ba \\
\hline & P-25 & $3566 \mathrm{Ab}$ & $4591 \mathrm{Bb}$ & $4673 \mathrm{Bb}$ \\
\hline & PO & $4205 \mathrm{Ac}$ & $5344 \mathrm{BC}$ & $5414 \mathrm{BC}$ \\
\hline & $\mathrm{P}+25$ & 4619 Ad & 5807Bd & $5902 B d$ \\
\hline & $P+50$ & $4811 \mathrm{Ad}$ & 6107Bd & $6169 \mathrm{Bd}$ \\
\hline \multirow[t]{5}{*}{ Lavras } & P-50 & $5348 \mathrm{Aa}$ & $5896 \mathrm{Ba}$ & $5852 \mathrm{Ba}$ \\
\hline & P-25 & $7632 A b$ & $8454 \mathrm{Bb}$ & $8473 \mathrm{Bb}$ \\
\hline & P0 & $8140 \mathrm{Ac}$ & $9327 \mathrm{BC}$ & $9360 \mathrm{BC}$ \\
\hline & $\mathrm{P}+25$ & $8054 A b c$ & $9625 \mathrm{BC}$ & $9612 \mathrm{BC}$ \\
\hline & $\mathrm{P}+50$ & $7908 \mathrm{Abc}$ & $9735 \mathrm{Bc}$ & $9629 \mathrm{BC}$ \\
\hline
\end{tabular}

Averages followed by the same uppercase letter in the line and lowercase case letter in the column do not differ statistically from each other by the Tukey test at $5 \%$ probability.

changes in rainfall (Table 6), it was observed that, for the scenario of $50 \%$ reduction in rainfall, the regions of Aimorés, Lavras, Machado, Paracatu, Pompéu and Viçosa, showed statistically different simulated yields for the three crop residue quantity scenarios $\left(0 ; 2 \mathrm{e} 4 \mathrm{t} \mathrm{ha}^{-1}\right)$. That is, at this level of water scarcity, increasing the amount of crop residue from 0 to 2 and from 2 to $4 \mathrm{t} \mathrm{ha}^{-1}$ is relevant in mitigating the effects of climate change. This is because the presence of crop residue in a well-established no-tillage system protects the soil surface, favoring the infiltration of water and also reducing the evaporation through the soil surface (Moreira et al., 2011). Touch et al. (2005), using the APSIM crop growth model in Cambodia, also showed the potential of using crop residues as a strategy to adapt maize to climate change. The authors observed the positive effect of increasing the amount of crop residue on the average maize yield. In another study, Dalmago et al. (2009) found higher soil-water retention and higher water availability to the plants in the top layers under no-tillage system as compared to conventional tillage systems. This result reiterates the relevance of maintaining crop residue in the soil surface as a strategy to reduce the impacts of water scarcity for plants, which reduces the direct evaporation of water by the soil surface due to the barrier created by the mulching, among other benefits.

When analyzing the scenarios of changes in solar radiation it was noted that there was a downward trend on the average yield of maize due to the reduction of solar radiation and vice-versa. In comparison to the baseline, the reduction in the solar radiation rate by $25 \%$ (Rad-25)
Table 6. Unfolding the analysis of variance for the interaction between crop residue and change in rainfall.

\begin{tabular}{|c|c|c|c|c|}
\hline \multirow{2}{*}{ Mesoregion } & \multirow{2}{*}{$\begin{array}{l}\text { Changes in } \\
\text { Rainfall }\end{array}$} & \multicolumn{3}{|c|}{ Crop Residue (t ha-1) } \\
\hline & & 0 & 2 & 4 \\
\hline \multirow[t]{5}{*}{ Aimorés } & $\mathrm{P}-50$ & $2690 \mathrm{Aa}$ & $3290 \mathrm{Ba}$ & $3684 \mathrm{Ca}$ \\
\hline & P-25 & $4288 \mathrm{Ab}$ & $4741 \mathrm{Bb}$ & $4944 \mathrm{Bb}$ \\
\hline & $\mathrm{PO}$ & $4942 A c$ & $5200 \mathrm{BC}$ & $5325 \mathrm{BC}$ \\
\hline & $\mathrm{P}+25$ & $5214 \mathrm{Ad}$ & $5432 \mathrm{Bcd}$ & $5519 \mathrm{Bcc}$ \\
\hline & $\mathrm{P}+50$ & $5400 \mathrm{Ad}$ & $5573 \mathrm{ABd}$ & $5650 \mathrm{Bd}$ \\
\hline \multirow[t]{5}{*}{ Lavras } & P-50 & $5129 \mathrm{Aa}$ & $5747 \mathrm{Ba}$ & $6220 \mathrm{Ca}$ \\
\hline & P-25 & $7758 \mathrm{Ab}$ & $8256 \mathrm{Bb}$ & $8544 \mathrm{Bb}$ \\
\hline & PO & $8732 A c$ & $8977 \mathrm{ABC}$ & $9116 \mathrm{BC}$ \\
\hline & $\mathrm{P}+25$ & $9037 \mathrm{Ac}$ & $9090 \mathrm{Ac}$ & $9165 \mathrm{Ac}$ \\
\hline & $P+50$ & $9085 \mathrm{Ac}$ & $9073 A c$ & $9113 A c$ \\
\hline \multirow[t]{5}{*}{ Machado } & P-50 & $4928 \mathrm{Aa}$ & $6396 \mathrm{Ba}$ & 7197Ca \\
\hline & P-25 & $6942 A b$ & $7930 \mathrm{Bb}$ & $8146 \mathrm{Bb}$ \\
\hline & P0 & $7878 \mathrm{Ac}$ & $8301 \mathrm{Bc}$ & $8408 \mathrm{Bbc}$ \\
\hline & $\mathrm{P}+25$ & $8232 \mathrm{Ad}$ & $8450 \mathrm{ABC}$ & $8520 \mathrm{BC}$ \\
\hline & $P+50$ & 8377Ad & $8527 A c$ & $8578 \mathrm{Ac}$ \\
\hline \multirow[t]{5}{*}{ Paracatu } & $P-50$ & 4989Aа & $5621 \mathrm{Ba}$ & $6006 \mathrm{Ca}$ \\
\hline & P-25 & $6620 A b$ & $6960 \mathrm{Bb}$ & $7104 \mathrm{Bb}$ \\
\hline & P0 & $7233 A c$ & $7401 \mathrm{ABC}$ & $7480 \mathrm{BC}$ \\
\hline & $\mathrm{P}+25$ & $7442 \mathrm{Acd}$ & $7541 \mathrm{Ac}$ & $7598 \mathrm{AC}$ \\
\hline & $\mathrm{P}+50$ & $7522 \mathrm{Ad}$ & $7582 \mathrm{Ac}$ & $7639 A C$ \\
\hline \multirow[t]{5}{*}{ Pompéu } & P-50 & $4758 \mathrm{Aa}$ & $5651 \mathrm{Ba}$ & $6127 \mathrm{Ca}$ \\
\hline & P-25 & $6884 A b$ & $7561 \mathrm{Bb}$ & $7797 \mathrm{Bb}$ \\
\hline & P0 & $7744 A c$ & $8047 \mathrm{BC}$ & $8143 B C$ \\
\hline & $\mathrm{P}+25$ & 8068Acd & $8222 \mathrm{Ac}$ & $8275 \mathrm{Ac}$ \\
\hline & $\mathrm{P}+50$ & $8208 \mathrm{Ad}$ & $8298 \mathrm{Ac}$ & $8326 \mathrm{Ac}$ \\
\hline \multirow[t]{5}{*}{ Viçosa } & P-50 & $4100 \mathrm{Aa}$ & 4798Ba & $5186 \mathrm{Ca}$ \\
\hline & P-25 & $5773 A b$ & $6193 \mathrm{Bb}$ & $6417 \mathrm{Bb}$ \\
\hline & P0 & $6436 \mathrm{Ac}$ & $6722 \mathrm{BC}$ & $6875 \mathrm{BC}$ \\
\hline & $\mathrm{P}+25$ & $6672 \mathrm{Acd}$ & $6962 \mathrm{Bcd}$ & $6956 \mathrm{Bcc}$ \\
\hline & $\mathrm{P}+50$ & $6829 \mathrm{Ad}$ & $7078 \mathrm{ABd}$ & $7210 \mathrm{Bd}$ \\
\hline
\end{tabular}

Averages followed by the same uppercase letter in the line and lowercase case letter in the column do not differ statistically from each other by the Tukey test at $5 \%$ probability.

impacted less maize yield in the well-corrected soil and a consolidated no-tillage system scenario (Rz70Cob4). As for the scenario of improperly corrected soil profile or with some resistance to root growth (Rz30), yield reductions were higher. Thus, it is inferred that both deeper root systems and a good amount of crop residue left in the soil surface, which provides increased albedo, present potential as mitigating strategies for the effects of changes in the incident solar radiation rate.

For all regions, the best management strategy to mitigate the effects of solar radiation reduction is the one that takes into consideration a good soil profile correction, with no impediment to root growth (Rz50 and Rz70) associated to a well-established no-tillage system (Cob4) (Figure 3). Also, in comparison to the baseline (Rz50Cob2), 
Figure 3. Percentage change in maize yield for different scenarios of changes in solar radiation and soil and crop management strategies.
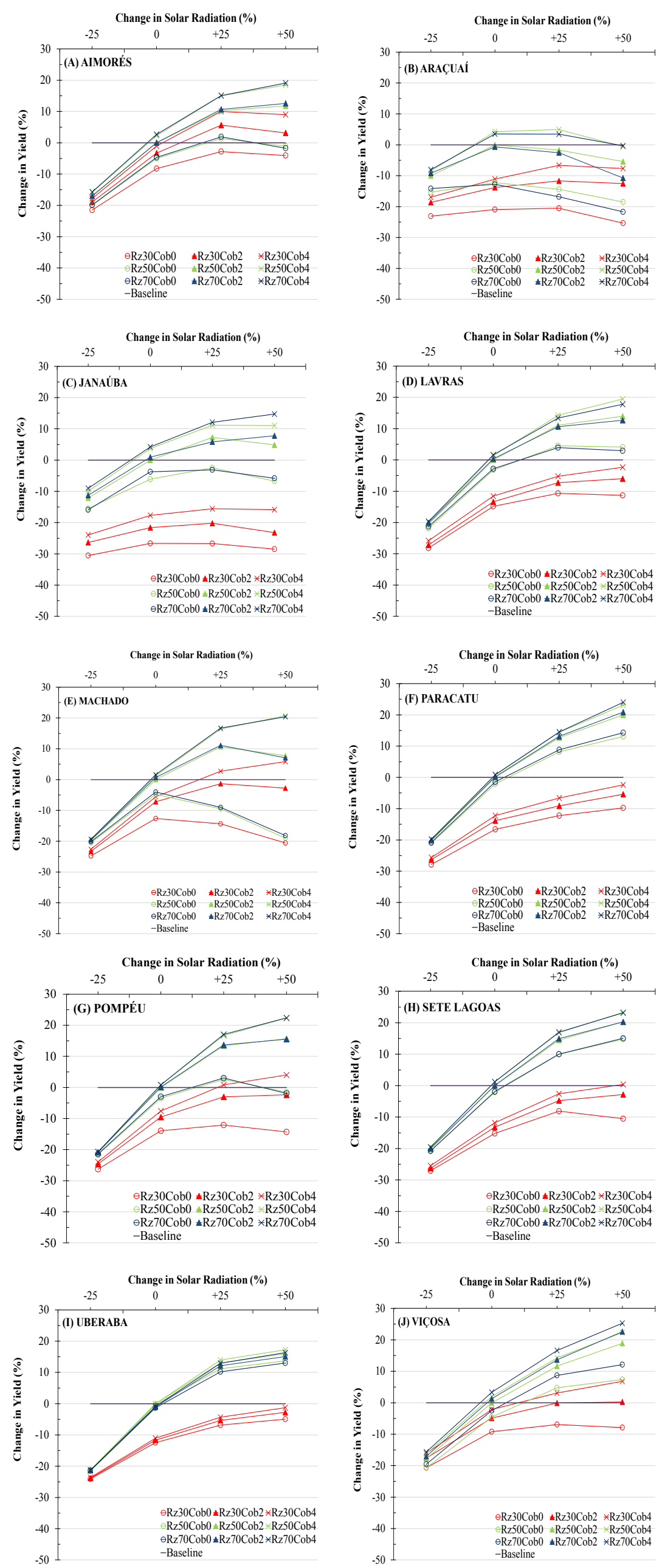
increasing the solar radiation by $25 \%$ and $50 \%$ promoted an increase in the average yield of maize for the majority of regions. Araçuaí, however, showed a decrease in yield by increasing $50 \%$ in the solar radiation rate (Figure 3B). The region presents low annual average rainfall, low total soil porosity, higher soil bulk density and low soil-water retention. The excess of incident solar radiation on a plant that is under water stress causes reduction in the efficiency of the photosynthesis process and, consequently, reduction in yield (Araújo \& Deminicis, 2009). The increment in solar radiation can also increases the crop evapotranspiration (Bergamaschi \& Matzenauer, 2014) which, for the same volume of rainfall and the same soil-water retention, leads to a drop in grain yield.

As compared to Araçuaí, the regions of Machado and Pompéu presented a more pronounced drop in yield due to increase of solar radiation in scenarios with no crop residue in the soil surface (Cobo), emphasizing the relevance of a well-established no-tillage system in these regions and also demonstrating how no-till favors greater solar radiation use efficiency.

The interactions root depth $\mathrm{x}$ solar radiation and coverage $\mathrm{x}$ solar radiation were unfolded to evaluate the effects on maize yield (Tables 7 and 8). When assessing the effect of the amount of crop residue left in the soil surface on yield, within each change in the solar radiation, it was observed that for Aimorés, Araçuaí, Lavras, Paracatu, Pompéu, Sete Lagoas and Viçosa, the behavior was the same when solar radiation was increased by $25 \%$. There was a statistically significant difference between the average yields obtained for the scenario without crop residue (Cobo). Thus, in the scenario of increased solar radiation, the adoption of a no-tillage system, which leaves crop residue in the soil surface, has the potential to mitigate the effects of this climate change due to the increased albedo. Silva et al. (2006) evaluated the effect of three management systems on soil temperature throughout cycle of an edible bean crop. They concluded that the notillage system provided lower maximum temperatures and lower thermal amplitude in the soil due to the increase of albedo that increases solar radiation reflectivity.

The presence of crop residue influences the interception of the photosynthetically active radiation and, therefore, the smaller decreases in yield are associated to the greater amount of residue left in the soil surface. Kunz et al. (2007) conducted a study in Eldorado do Sul, Brazil, indicated that maize grown under no-tillage system presented a greater efficiency to intercept the photosynthetically active radiation in relation to conventional tillage. The authors infer that this may be related to the higher leaf turgor due to the higher water availability for plants grown under notillage system.

When assessing the effect of root depth, within the
Table 7. Unfolding the analysis of variance for interaction between crop residue and change in solar radiation.

\begin{tabular}{|c|c|c|c|c|}
\hline \multirow{2}{*}{ Regions } & \multirow{2}{*}{$\begin{array}{l}\text { Change in Solar } \\
\text { Radiation }\end{array}$} & \multicolumn{3}{|c|}{ Crop Residue (t ha-1) } \\
\hline & & 0 & 2 & 4 \\
\hline \multirow[t]{4}{*}{ Aimorés } & Rad-25 & $4182 \mathrm{Aa}$ & $4328 \mathrm{Aa}$ & $4392 \mathrm{Aa}$ \\
\hline & Rad0 & $4942 A b$ & $5200 \mathrm{Bb}$ & $5325 \mathrm{Bb}$ \\
\hline & $\operatorname{Rad}+25$ & $5263 \mathrm{Ac}$ & $5721 \mathrm{Bc}$ & $5959 \mathrm{BC}$ \\
\hline & $\mathrm{Rad}+50$ & $5136 \mathrm{Abc}$ & $5739 \mathrm{BC}$ & $6073 \mathrm{Cc}$ \\
\hline \multirow[t]{4}{*}{ Araçuaí } & Rad-25 & $4251 \mathrm{Aa}$ & $4505 \mathrm{ABa}$ & $4580 \mathrm{Ba}$ \\
\hline & Rad0 & $4365 \mathrm{Aa}$ & $4905 \mathrm{Bb}$ & $5097 \mathrm{Bb}$ \\
\hline & $\operatorname{Rad}+25$ & $4264 \mathrm{Aa}$ & $4880 \mathrm{Bb}$ & $5185 \mathrm{Bb}$ \\
\hline & $\mathrm{Rad}+50$ & $4029 \mathrm{Aa}$ & 4661Bab & $5007 \mathrm{Cb}$ \\
\hline \multirow[t]{4}{*}{ Lavras } & Rad-25 & 7154Aa & $7264 \mathrm{Aa}$ & $7341 \mathrm{Aa}$ \\
\hline & Rad0 & $8732 A b$ & $8977 \mathrm{Ab}$ & $9116 \mathrm{Ab}$ \\
\hline & $\operatorname{Rad}+25$ & $9318 \mathrm{Ac}$ & $9838 \mathrm{BC}$ & $10088 \mathrm{Bc}$ \\
\hline & $\operatorname{Rad}+50$ & $9252 \mathrm{Ac}$ & $10032 \mathrm{BC}$ & $10479 \mathrm{Co}$ \\
\hline \multirow[t]{4}{*}{ Machado } & Rad-25 & $6635 \mathrm{Aa}$ & $6712 \mathrm{Aa}$ & $6747 \mathrm{Aa}$ \\
\hline & Rad0 & 7878Ab & $8301 \mathrm{Bb}$ & $8408 \mathrm{Bb}$ \\
\hline & $\operatorname{Rad}+25$ & $7555 \mathrm{Ab}$ & $9063 \mathrm{BC}$ & $9498 \mathrm{Cc}$ \\
\hline & $\operatorname{Rad}+50$ & $6851 \mathrm{Aa}$ & $8826 \mathrm{BC}$ & $9813 \mathrm{Cc}$ \\
\hline \multirow[t]{4}{*}{ Paracatu } & Rad-25 & $5951 \mathrm{Aa}$ & 6033Aa & $6066 \mathrm{Aa}$ \\
\hline & Rad0 & $7233 \mathrm{Ab}$ & $7401 \mathrm{Ab}$ & $7480 \mathrm{Ab}$ \\
\hline & $\operatorname{Rad}+25$ & $7877 \mathrm{Ac}$ & $8186 \mathrm{BC}$ & $8331 \mathrm{Bc}$ \\
\hline & $\operatorname{Rad}+50$ & $8210 \mathrm{Ad}$ & 8672Bd & $8910 \mathrm{Bd}$ \\
\hline \multirow[t]{4}{*}{ Pompéu } & Rad-25 & $6388 \mathrm{Aa}$ & $6468 \mathrm{Aa}$ & $6496 \mathrm{Aa}$ \\
\hline & Rad0 & 7744Ab & $8047 \mathrm{ABb}$ & $8143 B b$ \\
\hline & $\operatorname{Rad}+25$ & $8129 \mathrm{Ac}$ & $8972 \mathrm{BC}$ & $9265 \mathrm{Bc}$ \\
\hline & $\operatorname{Rad}+50$ & $7816 \mathrm{Abc}$ & $9106 \mathrm{BC}$ & $9655 \mathrm{Cd}$ \\
\hline \multirow[t]{4}{*}{ Sete Lagoas } & Rad-25 & $6628 \mathrm{Aa}$ & $6690 \mathrm{Aa}$ & $6741 \mathrm{Aa}$ \\
\hline & Rad0 & 8037Ab & $8211 \mathrm{Ab}$ & $8317 A b$ \\
\hline & $\operatorname{Rad}+25$ & $8925 \mathrm{Ac}$ & $9292 \mathrm{BC}$ & $9482 \mathrm{Bc}$ \\
\hline & Rad+50 & $9139 \mathrm{Ac}$ & $9667 \mathrm{Bd}$ & $9928 \mathrm{Bd}$ \\
\hline \multirow[t]{4}{*}{ Viçosa } & Rad-25 & 5421Aa & $5615 \mathrm{ABa}$ & 5717Ba \\
\hline & Rad0 & $6436 \mathrm{Ab}$ & $6722 \mathrm{Bb}$ & $6875 \mathrm{Bb}$ \\
\hline & $\operatorname{Rad}+25$ & $6951 \mathrm{Ac}$ & $7375 \mathrm{BC}$ & $7574 \mathrm{Bc}$ \\
\hline & $\operatorname{Rad}+50$ & $7066 \mathrm{Ac}$ & 7751Bd & $8039 \mathrm{Cd}$ \\
\hline
\end{tabular}

Averages followed by the same uppercase letter in the line and lowercase case letter in the column do not differ statistically from each other by the Tukey test at $5 \%$ probability.

changes in solar radiation, two distinct results were observed when reducing solar radiation by $25 \%$ (Rad-25). Pompéu, Uberaba and Viçosa did not present statistical differences in yield for the three levels of root depth evaluated. That is, the effect of the root system depth was not significant in these places when the solar radiation was reduced. Janaúba, Lavras, Paracatu and Sete Lagoas, in turn, presented significant difference for the shallow root system (Rz30). At these sites, deeper root systems, or better corrected soils, minimize the effects of reduced solar radiation.

The study took into account only linear and individualized changes in the meteorological variables. 
Table 8. Unfolding the analysis of variance for interaction between root system depth and solar radiation change.

\begin{tabular}{|c|c|c|c|c|}
\hline \multirow{2}{*}{ Mesoregion } & \multirow{2}{*}{$\begin{array}{l}\text { Change in } \\
\text { Solar Radiation }\end{array}$} & \multicolumn{3}{|c|}{ Root System Depth (m) } \\
\hline & & 0.3 & 0.5 & 0.7 \\
\hline \multirow[t]{4}{*}{ Janaúba } & Rad-25 & 3936Aa & $4712 \mathrm{Ba}$ & 4739Ba \\
\hline & Rad0 & 4205Aab & $5344 \mathrm{Bb}$ & $5414 \mathrm{Bb}$ \\
\hline & $\operatorname{Rad}+25$ & $4266 \mathrm{Ab}$ & $5673 B \mathrm{C}$ & $5654 \mathrm{Bb}$ \\
\hline & $\operatorname{Rad}+50$ & 4175Aab & $5553 \mathrm{Bbc}$ & $5688 \mathrm{Bb}$ \\
\hline \multirow[t]{4}{*}{ Lavras } & Rad-25 & $6849 A a$ & 7434Ba & $7475 \mathrm{Ba}$ \\
\hline & Rad0 & $8140 A b$ & $9327 \mathrm{Bb}$ & $9360 \mathrm{Bb}$ \\
\hline & $\mathrm{Rad}+25$ & $8662 A c$ & $10322 \mathrm{BC}$ & $10259 \mathrm{BC}$ \\
\hline & $\mathrm{Rad}+50$ & $8770 A c$ & $10562 \mathrm{BC}$ & $10431 \mathrm{Bc}$ \\
\hline \multirow[t]{4}{*}{ Paracatu } & Rad-25 & $5689 \mathrm{Aa}$ & $6175 \mathrm{Ba}$ & $6186 \mathrm{Ba}$ \\
\hline & Rad0 & $6650 \mathrm{Ab}$ & $7719 \mathrm{Bb}$ & $7744 \mathrm{Bb}$ \\
\hline & $\operatorname{Rad}+25$ & $7032 \mathrm{Ac}$ & $8666 \mathrm{BC}$ & $8697 \mathrm{Bc}$ \\
\hline & $\mathrm{Rad}+50$ & $7301 \mathrm{Ac}$ & 9207Bd & 9284Bd \\
\hline \multirow[t]{4}{*}{ Pompéu } & Rad-25 & $6533 \mathrm{Aa}$ & $6556 \mathrm{Aa}$ & $6564 \mathrm{Aa}$ \\
\hline & Rad0 & $7448 \mathrm{Ab}$ & $8235 \mathrm{Bb}$ & $8251 \mathrm{Bb}$ \\
\hline & $\operatorname{Rad}+25$ & $7911 \mathrm{Ac}$ & $9212 \mathrm{BC}$ & $9242 \mathrm{Bc}$ \\
\hline & $\operatorname{Rad}+50$ & $7957 \mathrm{Ac}$ & $9318 \mathrm{BC}$ & 9303Bc \\
\hline \multirow[t]{4}{*}{ Sete Lagoas } & Rad-25 & $6330 \mathrm{Aa}$ & $6872 \mathrm{Ba}$ & $6857 \mathrm{Ba}$ \\
\hline & Rad0 & $7436 \mathrm{Ab}$ & $8559 \mathrm{Bb}$ & $8569 \mathrm{Bb}$ \\
\hline & $\operatorname{Rad}+25$ & $8144 A c$ & $9768 \mathrm{BC}$ & $9787 \mathrm{Bc}$ \\
\hline & $\mathrm{Rad}+50$ & $8215 A c$ & 10257Bd & $10262 \mathrm{Bd}$ \\
\hline \multirow[t]{4}{*}{ Uberaba } & Rad-25 & $7283 \mathrm{Aa}$ & 7533Аа & $7520 \mathrm{Aa}$ \\
\hline & Rad0 & $8439 A b$ & $9549 \mathrm{Bb}$ & $9456 \mathrm{Bb}$ \\
\hline & $\mathrm{Rad}+25$ & $9034 \mathrm{Ac}$ & $10775 \mathrm{BC}$ & $10685 \mathrm{BC}$ \\
\hline & $\operatorname{Rad}+50$ & $9271 \mathrm{Ac}$ & $11054 \mathrm{BC}$ & $10976 \mathrm{BC}$ \\
\hline \multirow[t]{4}{*}{ Viçosa } & Rad- 25 & $5572 \mathrm{Aa}$ & $5562 A a$ & $5620 \mathrm{Aa}$ \\
\hline & Rad0 & $6436 \mathrm{Ab}$ & $6745 \mathrm{Bb}$ & $6851 \mathrm{Bb}$ \\
\hline & $\operatorname{Rad}+25$ & $6714 A c$ & $7500 \mathrm{Bc}$ & $7686 \mathrm{Bc}$ \\
\hline & $\operatorname{Rad}+50$ & $6785 \mathrm{Ac}$ & $7906 \mathrm{Bd}$ & $8164 \mathrm{Bd}$ \\
\hline
\end{tabular}

Averages followed by the same uppercase letter in the line and lowercase case letter in the column do not differ statistically from each other by the Tukey test at $5 \%$ probability.

New studies are recommended using global circulation models capable of generating future data with simultaneous changes in climate elements.

\section{Conclusions}

The largest drop in maize average yield, compared to the unchanged climate scenario, are due to reductions in rainfall, especially in regions with high air temperature. The presence of residue of the previous crop on the soil surface shows statistically significant interactions with the rainfall changes, and therefore, in most of the regions studied, the use of that management strategy is more effective to mitigate such effects than the use of a cultivar with deep root system, as compared to the unchanged climate scenario. In most of the regions, the combination of maize cultivars presenting a root depth of $0.7 \mathrm{~m}$ with $4 \mathrm{t}$ $\mathrm{ha}^{-1}$ of residue left on the soil surface by the previous crop, provides the smallest yield breaks under reducing rainfall scenarios.

The increase of solar radiation favors yield increment, except for Araçuaí where water stress nullified the positive effect of this increase. The reduction, however, negatively affects the maize yield. Both the depth of root system and the amount of crop residue present significant statistical interaction with changes in solar radiation, which indicates potential to mitigate the effect of these modifications.

\section{Acknowledgment}

To Dr. Elena Charlotte Landau my sincere thanks for preparing the map with the counties location.

\section{References}

ALBUQUERQUE, P. E. P. Manejo de irrigação. In: Cultivo do milho. Sete Lagoas: Embrapa Milho e Sorgo, 2010. Sistema de Produção, 1. 6 $6^{\underline{a}}$ edição. Versão eletrônica. https://ainfo.cnptia.embrapa.br/digital/bitstream/ item/81707/1/Manejo-irrigacao.pdf.

ALVES, M. E. B.; ANDRADE, C. L. T.; CÁRDENAS, R. R.; AMARAL, T. A.; SILVA, D. F. Identificação e quantificação do efeito de fatores ambientais na produtividade da cultura do milho na região de Janaúba, MG. Revista Brasileira de Agricultura Irrigada-RBAI, Fortaleza, v. 5, n. 3, p. 188201, 2011.

AMADU, F. O.; MILLER, D. C.; McNAMARA, P. E. Agroforestry as a pathway to agricultural yield impacts in climate-smart agriculture investments: Evidence from southern Malawi. Ecological Economics. 2020; 167:106443.

ANDRADE, C. L. T.; SILVA, P. P. G.; MAGALHÃES, B. G.; PAIXÃO, J. S.; MELO, B. F.; TIGGES, C. H. P. Parametrização do modelo CSM-CERESMaize para uma cultivar de alta produtividade. In: XXXI Congresso Nacional de Milho e Sorgo, Bento Gonçalves, RS, 2016. Anais... Sete Lagoas: Associação Brasileira de Milho e Sorgo, 2016.

ARAÚJO, S. A. C.; DEMINICIS, B. B. Fotoinibição da fotossíntese. Revista Brasileira de Biociências, Porto Alegre, v. 7, n. 4, p. 463-472, 2009.

BERGAMASCHI, H.; MATZENAUER, R. O milho e o clima. Porto Alegre: Emater/RS-Ascar, 2014. 85p.

BERGAMIN, A.C.; VITORINO, A.C.T.; LEMPP, B.; SOUZA, C.M.A.; SOUZA, F.R. Anatomia radicular de milho em solo compactado. Pesquisa Agropecuária Brasileira, Brasília, v.45, n.3, p.299-305, 2010.

BRAGANÇA, R.; SANTOS, A. R.; SOUZA, E. F.; CARVALHO, A. J. C.; LUPPI, A. S. L.; SILVA, R. G. Impactos das mudanças climáticas no zoneamento agroclimatológico do café arábica no Espírito Santo. Revista Agro@ mbiente On-line, Boa Vista, v. 10, n. 1, p. 77-82, 2016.

CASTILLO, A. C. Efeito das mudanças climáticas sobre a demanda de água para irrigação e o rendimento de grãos da cultura da soja na bacia do rio Potiribu. 2016. 79 p. Dissertação (Mestrado em Recursos Hídricos e Saneamento Ambiental) - Universidade Federal do Rio Grande do Sul, Porto Alegre.

CECCON, G. Milho safrinha com solo protegido e retorno econômico em Mato Grosso do Sul. Revista Plantio Direto, Passo Fundo, ano 16, n. 97 p. 17-20, jan./fev. 2007.

DALMAGO, G. A.; BERGAMASCHI, H.; BERGONCI, J. I.; KRUGER, C. A. M. B.; COMIRAN, F.; HECKLER, B. M. M. Retenção e disponibilidade de água às plantas, em solo sob plantio direto e preparo convencional. Revista Brasileira de Engenharia Agrícola e Ambiental, Campina Grande. Vol. 13, supl., (out. 2009), p. 855-864, 2009. 
DEKALB. Informações sobre o híbrido DKB 390. Available at: https:// www.dekalb.com.br/pt-br/nossos-produtos/hibridos-milho/verao/dkb390.html Access in: May 20, 2019.

FAO. Food and Agriculture Organization. Water and soil requirements. In: W. Critchley, and K. Siegert eds. Water Harvesting (AGL/MISC/17/91) - A Manual for the Design and Construction of Water Harvesting Schemes for Plant Production. http://www.fao.org/docrep/u3160e/ u3160e04.htm\#2. 1991 (Access on May 21, 2019).

FERREIRA, D. F. Sisvar: a computer statistical analysis system. Ciência e Agrotecnologia, Lavras, v. 35, n. 6, p. 1039-1042, 2011.

FOLBERTH, C.; YANG, H.; GAISER, T.; LIU, J.; WANG, X.; WILLIAMS, J.; SCHULIN, R. Effects of ecological and conventional agricultural intensification practices on maize yields in sub-Saharan Africa under potential climate change. Environmental Research Letters, v. 9, n. 4, p. 01-12, 2014.

FRANCHINI, J.C.; COSTA, J.M.; DEBIASI, H.; TORRES, E. Importância da rotação de culturas para a produção agrícola sustentável no Paraná. Londrina: Embrapa Soja, 2011. p.52. (Documentos, 327).

GENG, X.; WANG, F.; REN, W.; HAO, Z. Climate change impacts on winter wheat yield in Northern China. Advances in Meteorology, V.2019, 1-12. https://doi.org/10.1155/2019/2767018

HOOGENBOOM, G.; PORTER, C. H.; SHELIA, V.; BOOTE, K. J.; SINGH, U.; WHITE, J. W.; HUNT, L. A.; OGOSHI, R.; LIZASO, J. I.; KOO, J.; ASSENG, S.; SINGELS, A.; MORENO, L. P.; JONES. J. W. Decision Support System for Agrotechnology Transfer (DSSAT) Version 4.7 (https://DSSAT.net). DSSAT Foundation, Gainesville, Florida, USA. 2017.

INSTITUTO brasileiro de geografia e estatística (IBGE). Levantamento Sistemático da Produção Agrícola. 2020. Available at: https://sidra.ibge. gov.br/tabela/1618. Accessed on January 14, 2020.

IPCC, 2013. Climate Change 2013: The Physical Science Basis. Contribution of Working Group I to the Fifth Assessment Report of the Intergovernmental Panel on Climate. Cambridge, United Kingdom/New York, NY, USA: Cambridge University Press; 2013

IPCC, 2014: Climate Change 2014: Synthesis Report. Contribution of Working Groups I, II and III to the Fifth Assessment Report of the Intergovernmental Panel on Climate Change [Core Writing Team, R.K. Pachauri and L.A. Meyer (eds.)]. IPCC, Geneva, Switzerland, 151 pp. Available at: https://archive.ipcc.ch/report/ar5/syr/. Access in May 21, 2019.

JONES, J. W.; HOOGENBOOM, G.; PORTER, C. H.; BOOTE, K. J.; BATCHELOR, W. D.; HUNT, L. A.; WILKENS, P. W.; SINGH, U.; GIJSMAN, A. J.; RITCHIE, J. T. The DSSAT cropping system model. European Journal of Agronomy, Montpellier, v. 18, n. 3, p. 235-265, 2003.

KELL, D. B. Breeding crop plants with deep roots: their role in sustainable carbon, nutrient and water sequestration. Annals of Botany 108: 407-418, 2011. doi:10.1093/aob/mcr175, available online at www. aob.oxfordjournals.org.

LABEGALINI, N.S.; BUCHELT, A.C.; ANDRADE, L.; OLIVEIRA, S.C.; CAMPOS, L.M. Desenvolvimento da cultura do milho sob efeitos de diferentes profundidades de compactação de solo. Revista de Agricultura Neotropical, Cassilândia, v.3, p.7-11, 2016.
MORAES, W. B.; JESUS JÚNIOR, W. C.; MORAES, W. B.; CECÍLIO, R. A. Potenciais impactos das mudanças climáticas globais sobre a agricultura. Revista Trópica-Ciências Agrárias e Biológicas, Chapadinha, v. 5, n. 2, p. 3-14, 2011

MORAES, M. T. Modelagem do crescimento radicular de milho e soja sujeito a estresses hídrico e mecânico em latossolo. 2017.122p. Tese (Doutorado em Ciência do solo). Universidade Federal do Rio Grande do Sul, Porto Alegre.

MOREIRA, J. A. A.; STONE, L. F.; PEREIRA FILHO, I. A.; CRUZ, J. C. Eficiência de uso de água pela cultura do milho (Zea mays) em função da cobertura do solo pela palhada no sistema plantio direto. Cadernos de Agroecologia, V6, n.2, p.1-6, 2011.

MULUNGU, K.; NG'OMBE, J. N. Climate Change Impacts on Sustainable Maize Production in Sub-Saharan Africa: A Review. 2019. DOI: http://dx.doi.org/10.5772/intechopen.90033

NASA earth observatory. Global warming. 2010. Available at: https:// earthobservatory.nasa.gov/features/GlobalWarming/page2.php. Accessed on January 14, 2020.

PICKERING, N. B.; HANSEN, J. W.; JONES, H.; GODWIN, D. Weatherman: a utility for managing and generating daily weather data. Agronomy Journal, Madison, v.86, n.2, p. 332-337, 1994

RODRIGUES, E. J.; CARAMORI, P. H.; MORAIS, H.; BIANCO, R. Profundidade de raízes de milho safrinha em sucessão com soja em três sistemas de cultivos no norte do paraná. Proceedings... Seminário Nacional de Milho Safrinha - Construindo Sistemas de Produção Sustentáveis e Rentáveis. Cuiabá, 21 a 23 de novembro de 2017.

SANTOS, R. S. D.; COSTA, L. C.; SEDIYAMA, G. C.; LEAL, B. G.; OLIVEIRA R. A. D.; JUSTINO, F. B. Avaliação da relação seca/produtividade agrícola em cenário de mudanças climáticas. Revista Brasileira de Meteorologia, São José dos Campos, v. 26, n. 2, p. 313-321, 2011.

TIGCHELAARA, M.; BATTISTIA, D. S.; NAYLORB, R. L.; RAYC, D. K. Future warming increases probability of globally synchronized maize production shocks. Proceedings of the National Academy of Sciences. v.115, n.26, p.6644-6649, 2018.

TOUCH, V.; MARTIN, R.; LIU, D. L.; COWIE, A.; SCOTT, F.; WRIGHT, G.; CHAUHAN, Y. Simulation modelling of alternative strategies for climate change adaptation in rainfed cropping systems in North-Western Cambodia. In: 17th Australian Society of Agronomy Conference, 2015, Hobart. Proceedings... Hobart: Australian Society of Agronomy, 2015.

ZANDONÁ, R. R.; BEUTLER, A. N.; BURG, G. M.; BARRETO, C. F.; SCHMIDT, M. R. Gesso e calcário aumentam a produtividade e amenizam o efeito do déficit hídrico em milho e soja. Pesquisa Agropecuária Tropical, Goiânia, v. 45, n. 2, p. 128-137, 2015.

WALTER, L. C.; STRECK, N. A.; ROSA, H. T.; FERRAZ, S. E. T.; CERA, J. C. Mudanças climáticas e seus efeitos no rendimento de arroz irrigado no Rio Grande do Sul. Pesquisa Agropecuária Brasileira, Brasília, v. 49, n. 12, p. 915-924, 2014. 


\section{Mitigação do efeito do clima futuro na produtividade de milho}

Bruna Gomes Magalhães ${ }^{1}$, Camilo de Lelis Teixeira de Andrade ${ }^{2(*)}$, Daniela de Carvalho Lopes ${ }^{3}$, Antonio José Steidle Neto ${ }^{3}$ e Tales Antônio Amaral ${ }^{2}$

${ }^{1}$ União Pioneira de Integração Social. SEPS Q 712/912 Conj. A, Asa Sul, CEP 70390-125 Brasília, DF. E-mail: edu.brunamagalhaes@gmail.com.

${ }^{2}$ Embrapa Milho e Sorgo. Rodovia MG 424, km 45, P.O. Box 285 or 151, CEP 35701-970 Sete Lagoas, MG.

E-mails: camilo.andrade@embrapa.br and tales_aamaral@yahoo.com.br.

${ }^{3}$ Universidade Federal de São João del Rei. Rodovia MG 424, km 47, CEP 35701-970 Sete Lagoas, MG.

E-mails: danielalopes@ufsj.edu.br and antonio@ufsj.edu.br.

${ }^{(*)}$ Autor para correspondência.

\section{INFORMAÇÕES}

\section{História do artigo:}

Recebido em 23 de julho de 2019

Aceito em 11 de março de 2020

Termos para indexação:

aquecimento global,

estratégias de mitigação

modelagem matemática

Zea mays L.

\section{RESUMO}

Alterações do clima em curso afetam a produção agrícola. Estratégias de manejo de cultura podem ser utilizadas para mitigar esses efeitos. Este estudo foi realizado com o objetivo avaliar o uso de estratégias de manejo de cultura e de solo para mitigar os efeitos do clima futuro na produtividade do milho em mesorregiões do estado de Minas Gerais, Brasil. O modelo CSM-CERES-Maize foi empregado para simular o efeito da profundidade do sistema radicular do milho e da quantidade de palhada, deixada na superfície do solo pela cultura anterior, na produtividade do milho, para diferentes cenários de alteração na precipitação e radiação solar. A diminuição no volume de chuvas reduziu em mais de $50 \%$ o rendimento médio do milho em algumas regiões. $O$ aumento da radiação solar favoreceu o incremento da produtividade, enquanto sua redução causou queda de mais de $20 \%$ no rendimento, na maioria dos municípios. As estratégias de manejo avaliadas têm potencial para mitigarem tais efeitos. 